\title{
Setting of Angle of Soil Flow on Ploughshare at Traditional Processing of Soil
}

Stanislav Petrásek, Miroslav Müller

Faculty of Engineering, Czech University of Life Sciences Prague. Czech Republic. E-mail: petrasek@tf.czu.cz.

The soil is a considerable abrasive medium which exerts on tools processing the soil in a negative way. The main problem connected with using the soil processing machines is their wear owing to particles embedded in the soil. The ploughshare is one of the most loaded parts of the ploughing body and huge requirements are put on it. The aim of the research is to set an angle of a soil flow and connected wear of the ploughshare at the traditional processing of the soil. It is possible to further issue from ascertained pieces of knowledge at a production/renovation of the ploughshares with new functional surface. The statistical analysis evidenced that the angle of the soil flow on the ploughshare surface was the same with the angle of the ploughshare head. It followed from the measurements that the optimum angle for depositing the oblique overlay which is necessary for the creation of the serrated edge is in the interval $35 \pm 4^{\circ}$.

Keywords: Composite, Functional surface, Optical analysis, Steel, Wear

\section{Acknowledgement}

This paper has been done when solving the grant IGA TF (No.: 2014:31140/1312/3133).

\section{References}

[1] MÜLLER, M., CHOTĚBORSKÝ, R., VALÁŠEK, P., HLOCH, S. (2013). Unusual Possibility of Wear Resistance Increase Research in the Sphere of Soil Cultivation. In: Tehnicki Vjesnik-Technical Gazette, Vol. 20, No 4, pp. 641-646.

[2] MÜLlER, M., NOVÁK, P., HRABĚ, P. (2012). Innovation of material - constructional solutions of ploughing blade in area of conventional processing of soil during cultivating sugar beet. In: Listy cukrovarnické a řepařské, Vol. 130, No 3. pp. 94-99.

[3] MÜLLER, M., HRABĚ, P. (2013). Overlay materials used for increasing lifetime of machine parts working under conditions of intensive abrasion. In: Research in Agricultural Engineering, Vol. 59, No 1. pp. 16-22.

[4] DOUBEK, P., FILÍPEK, J. (2011). Abrasive and erosive wear of technical materials. In: Acta Universitatis Agriculturae et Silviculturae Mendelianae Brunensis, 59(3), pp. 13-21.

[5] HORVAT, Z., FILIPOVI, D., KOSTIC, S., EMERT, R. (2008). Reduction of mouldboard plough share wear by a combination technique of hardfacing. In: Tribology International, Vol. 4. pp. 778-782.

[6] KEJVAL, J., MÜLLER, M. (2013). Mechanical properties of multi-component polymeric composite with particles of Al2O3/SiC. In: Scientia Agriculturae Bohemica, Vol. 44, No 4, pp. 237-242.

[7] MÜLLER, M., VALÁŠEK, P. (2012). Abrasive wear effect on Polyethylene, Polyamide 6 and polymeric particle composites. In: Manufacturing Technology, Vol. 12, No. 12, pp. 55-59.

[8] VOTAVA, J. et al. (2007). Abrasive wear of ploughshare blades made of Austempered Ductile Iron. In: Acta Universitatis Agriculturae et Silviculturae Mendelianae Brunensis, Vol. 55, No. 1, pp173-182.

[9] NATSIS, A., PAPADAKIS, G., PITSILIS J., (1999). The influence of soil type, soil water and share sharpness of a mouldboard plough on energy consumption, rate of work and tillage quality. In: Journal of Agricultural Engineering Research, Vol. 72, No. 2, pp. 171-176.

[10] NATSIS, A., PETROPOULOS, G., PANDAZARAS, C. (2008). Influence of local soil conditions on mouldboard ploughshare abrasive wear. In: Tribology International, Vol. 41, No. 3. pp. 151-157.

[11] CHOTĚBORSKÝ, R., HRABĚ, P., MÜLlER, M., SAVKOVÁ, J., JIRKA, M. (2008). Abrasive wear of high chromium Fe-Cr-C hardfacing alloys. In: Research of Agriculture Engineering, Vol. 54, No. 4. pp. 192-198.

[12] MÜLLER, M., VALÁŠEK, P., NOVÁK, P., HRABĚ, P., PAŠKO, J. (2011). Overlays and composites application in technology of sugar beet cultivation and harvest. In: Listy cukrovarnické a řepařské, Vol. 127, No 9. pp. 304307.

[13] HRABĚ, P., MÜLlER, M. (2013). Research of overlays influence on ploughshare lifetime. In: Research in Agricultural Engineering, Vol. 59, No. 4. pp. 147-152. 
[14] KIM, I. S., SON, K. J., YANG, Y. S., YARAGADA, P. K. D. V. (2013). Sensitivity analysis for process parameters in GMA welding processes using a factorial design method. In: International Journal of Machina Tools and Manufacture, Vol. 43, pp. 763-769.

[15] MÜLLER, M., VALÁŠEK, P. (2012). Polymeric particle composites with filler saturated matrix. In: Manufacturing Technology, Vol. 12, No 13. pp. 272-276.

[16] MÜLLER, M., VALÁŠEK, P. (2012). Abrasive wear effect on Polyethylene, Polyamide 6 and polymeric particle composites. In: Manufacturing Technology, Vol. 12, No 12. pp. 55-59.

[17] SATAPATHY, B.K., BIJWE, J. (2002). Analysis of simultaneous influence of operating variables on abrasive wear of phenolic composites. In: Wear, Vol. 253, pp. 787-794.

\section{Paper number: M201475}

Copyright $($ 2014. Published by Manufacturing Technology. All rights reserved. 